Research Article: Art

\title{
Ragam Hias Kalong dalam Senibina Masyarakat Orang Ulu di Sarawak
}

\author{
Lydia Patrick Padri' ${ }^{1}$, Harozila Ramli ${ }^{1}$ \\ ${ }^{1}$ Jabatan Seni dan Reka Bentuk. Fakulti Seni, Komputeran dan Industri Kreatif. \\ Universiti Pendidikan Sultan Idris, Malaysia.
}

Article History
Received:
04.11 .2021

Revised:
18.12 .2021
Accepted:
25.12 .2021
*Corresponding Author:
Lydia Patrick Padri
Email:
lydia6160@ymail.com

This is an open access article, licensed under: $\mathrm{CC}-\mathrm{BY}-\mathrm{SA}$

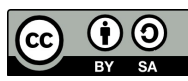

Abstrak: Kajian berkaitan ragam hias Kalong masyarakat Orang Ulu di Sarawak ini akan memberi fokus terhadap penggunaan Kalong pada senibina yang dihasilkan oleh masyarakat Orang Ulu di samping meneroka tentang makna dan falsafah yang terkandung di sebalik penggunaannya dari perspektif kepercayaan tradisi. Secara umumnya, kesenian dalam masyarakat Orang Ulu tradisional banyak menjurus kepada kepercayaan mistik dan alam ghaib serta mempunyai interaksi yang baik sesama manusia dan alam. Kajian kualitatif ini berdasarkan data-data yang dikumpul dalam bentuk perkataan, sumber majalah, keratan-keratan akhbar dan jurnal-jurnal hasil penulisan pengkaji-pengkaji barat dan tempatan serta lain-lain rekod rasmi. Di samping itu juga, kaedah temu bual dengan responden-responden yang dipilih yang terdiri daripada enam orang daripada kalangan masyarakat Orang Ulu itu sendiri juga menyokong kajian ini. Penemuan dan interpretasi yang dibuat akan dapat menjelaskan mengenai makna penggunaan motif-motif Kalong yang diaplikasikan pada binaan-binaan penting ini dengan lebih tepat lagi. Kajian ini juga dapat mengenal pasti beberapa penggiat yang terlibat dalam menghasilkan karya Kalong serta menjelaskan tentang makna dan falsafah serta mengenal pasti motif Kalong yang menjadi identiti masyarakat Orang Ulu.

Kata Kunci: Kalong, Komunitas Orang Ulu, Ragam Hias, Seni Bina.

Kalong Ornaments in the Architecture of the Orang Ulu Community in Sarawak

Abstract: This research is about the decoration in the architecture of the Orang Ulu community in Sarawak. It focuses on the use of the bat motifs, whose meaning and philosophy in the perspective of traditional beliefs are also explored. In the Orang Ulu communities, traditional arts are related to mystical and supernatural beliefs. Human beings and nature are believed to interact in harmony. This is a qualitative study in which data are collected, interviews jotted, articles in magazines, newspapers, journals, written by local as well as foreign researchers, and official records are gleaned. Six respondents from the Orang Ulu community are randomly interviewed to help verify the data. These are interpreted to see the significance of the architecture in the Orang Ulu communities. A number of carvers are identified who shed light on the bat motifs that embody the Orang Ulu identity.

Keywords: Architecture, Kalong, Orang Ulu Community, Ornaments. 


\section{Pendahuluan}

Ragam hias atau ornamen adalah bentuk dasar hiasan yang biasanya akan menjadi pola yang berulang dalam suatu karya kraf atau seni. Menurut Zainon [1], motif dan corak merupakan alat untuk melengkapkan ragam hias dengan cara mengatur dan menyusun apa yang ada dalam fikiran dan perasaan. Dalam konteks kajian ini, ragam hias Kalong adalah sebagai perlambangan sikap, keinginan dan lingkungan pemikiran masyarakat Orang Ulu. Ragam hias seperti apapun bentuknya, merupakan salah satu tayang kepuasan rohani manusia yang tidak bisa ditawar-tawar lagi [2]. Manakala menurut Hasuria Che Omar et al. [3], menjelaskan ragam hias adalah sebagai hiasan iaitu keperluan untuk mengindahkan, melengkapkan seni fungsi berkenaan, menyenangkan pembuat dan pengguna serta yang menyebabkan sesuatu artifak mengikat antaranya dengan artifak berkenaan. Ini menjelaskan bahawa ragam hias memiliki corak, warna serta bentuk yang beragam yang mengandungi makna dan falsafah tertentu kepada sesebuah masyarakat pembuatnya. Ragam hias atau ornamen adalah bentuk dasar hiasan yang biasanya akan menjadi pola yang berulang dalam sesebuah karya kraf atau seni. Karya ini boleh berupa tenunan, tulisan pada kain (contohnya batik), songket, ukiran, atau pahatan pada kayu atau batu. Ragam hias dapat digayakan (stylized) sehingga bentuknya bervariasi.

\section{Ragam Hias}

\subsection{Sifat Ragam Hias}

Ragam hias terdiri daripada pelbagai jenis motif. Ragam hias dapat dikelaskan kepada ragam hias naturalistik dan ragam hias stilistik (gaya). Manakala berdasarkan kepada elemen penciptaannya, ragam hias dapat dikategorikan kepada ragam hias geometri, flora atau tumbuh-tumbuhan, makhluk hidup iaitu yang terdiri daripada binatang dan manusia dan pelbagai jenis dekoratif. Motif-motif itulah yang digunakan sebagai penghias sesuatu yang akan dihias [4]. Ragam hias naturalistik merupakan ragam hias yang penciptaannya adalah hasil daripada peniruan atau bentuk-bentuk yang berilhamkan fenomena alam semulajadi. Ragam hias ini mudah dikenali terhadap bentuk gambarannya yang menyerupai objek-objek alam, contohnya ragam hias yang mengambarkan burung, dimana visualisasinya menyerupai bentuk-bentuk burung tertentu. Manakala, ragam hias stilistik (gaya) pula merupakan ragam hias yang penciptaan dan pembentukkan motifnya adalah berdasarkan kepada pengayaan terhadap elemen asas yang menjadi sumber rujukannya. Misalnya, gambaran bunga teratai yang dijadikan rujukan kelihatan berbeza dan tidak mudah dikenali seperti bunga teratai yang sebenar, kecuali pada bahagian-bahagian signifikan tertentu yang menjadi penandanya [5].

\subsection{Fungsi Ragam Hias}

Ragam hias dalam kehidupan masyarakat tidak hanya berfungsi sebagai elemen penghias bendabenda seperti perkakas, peralatan, perabot dan binaan, tetapi juga memiliki fungsi lain seperti fungsi suci, simbolik dan fungsi sosial. Dalam konteks kajian ini, ragam hias Kalong mencakupi fungsi magis dan fungsi simbolik, manakala fungsi sekular mencakupi elemen yang berkaitan dengan keindahan dan artistiknya. Ragam hias sejak dahulu kala digunakan untuk menyampaikan gagasan kosmologis dan metafisis dalam bentuk simbol dari generasi ke generasi [6].

\section{Kalong}

Kalong bermaksud seni ukiran, motif atau lukisan dalam masyarakat Orang Ulu [7]. Ketiga-tiga aspek ini disebut sebagai Kalong iaitu yang berbentuk motif dekoratif yang biasanya memiliki pola melingkar-lingkar yang mempunyai pelbagai makna dan tafsiran dalam konsep kepercayaan dan keagamaan masyarakat Orang Ulu tradisional. Kalong dalam masyarakat Orang Ulu digunakan dalam binaan serta peralatan lain adalah untuk menambahkan keindahannya. Walau bagaimanapun, motif dan ragam hiasnya adalah terkawal serta tidak mengatasi binaannya. Motif simbolik ini mempunyai pertalian mistik yang terletak pada persamaan di antara perkataan yang ditentukan pada setiap nama objek.

Kalong memainkan peranan yang sangat luas dan penting dalam masyarakat Orang Ulu. Selain digunakan sebagai ragam hias untuk tujuan mencantikkan sesuatu, Kalong berperanan sebagai mesej untuk memberitahu kepada orang lain tentang kebaikan dan kepimpinan golongan yang memiliki atau memakai motif tersebut. Ini merupakan sebahagian daripada adat dan tradisi dalam masyarakat Orang Ulu tradisi. Walaupun tidak terdapat bukti bertulis yang rasmi, yang ada hanya maklumat lisan dari warga tua dalam masyarakat Orang Ulu, seni motif Kalong dalam masyarakat Orang Ulu dipercayai berasal daripada mimpi serta kisah-kisah lagenda serta alam ghaib yang mempengaruhi 
corak dan gaya hidup Orang Ulu pada suatu ketika dahulu dan seterusnya diperturunkan dari generasi ke generasi.

Motif Kalong Orang Ulu biasanya membawa simbol atau melambangkan sesuatu maksud yang baik berdasarkan kepada cerita-cerita legenda, falsafah, sejarah dan tradisi dalam masyarakat Orang Ulu. Motif-motif Kalong Orang Ulu secara umumnya dapat dibahagikan kepada empat kategori iaitu flora, fauna dan manusia serta kosmos.

Terdapat beberapa jenis motif Kalong yang biasa digunakan pada binaan dalam masyarakat Orang Ulu iaitu yang terdiri daripada:

- Kalong Kelawit-Kawit (motif salur paut)

- Kalong Kayu Aren (pokok kehidupan)

- Kalong Penat

- Kalong Kelunan (motif manusia)

- Kalong Aso' / Naga Aso' (kombinasi naga dan anjing)

- Kalong Tebengang (enggang)

\subsection{Kalong Kelawit-Kawit}

Kalong Kelawit-Kawit (motif salur paut) (Gambar 1) yang diilhamkan daripada tumbuh-tumbuhan dikenali sebagai ukiran salur paut [8]. Setiap motif tradisi Orang Ulu lazimnya memiliki sifat-sifat tersebut dan digunakan secara meluas oleh para pelukis Orang Ulu. Motif Kalong Kelawit-kawit ini diilhamkan daripada tumbuh-tumbuhan iaitu yang memiliki bentuk seperti salur paut tumbuhan sama ada berdahan ataupun dipautkan pada mana-mana bahagian motif berkenaan [9]. Penggunaan Kalong Kelawit-kawit pada sesebuah binaan dalam masyarakat Orang Ulu adalah sangat penting kerana peranannya sebagai pelengkap kepada motif-motif utama agar motif utama tidak kelihatan kosong. Lazimnya akan digabungkan dengan motif utama dalam sesuatu ragam hias kerana peranannya dalam menyeimbangkan ruang agar sesebuah motif berkenaan tidak kelihatan kosong.

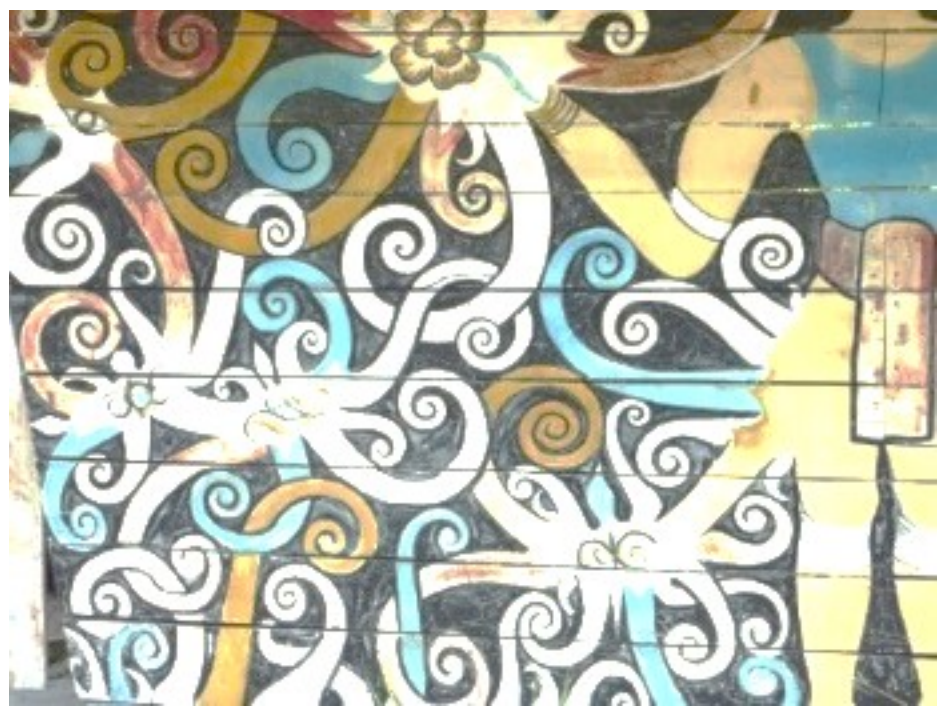

Gambar 1. Kalong Kelawit-Kawit

\subsection{Kalong Kayu Aren}

Kalong Kayu Aren (pokok kehidupan) atau lebih popular dengan gelaran 'The tree of life' (Gambar 2) ini diilhamkan daripada pemerhatian ke atas pokok ara. Motif Kayu Aren terdapat dalam tulisan beberapa pengkaji dan penulis seperti Sellato, Winzeler dan Valerie Mashman. Kalong Kayu Aren bermula dengan perkataan asal iaitu 'maren' yang bermaksud 'kelas bangsawan' dalam status sosial masyarakat Orang Ulu. Oleh yang demikian, motif ini adalah sebagai tanda bahawa ketua rumah panjang tersebut ialah seorang ketua yang bijaksana serta berkemampuan untuk membimbing anak buahnya. Selain itu, ilustrasi pokok kehidupan melambangkan pencipta dunia kaum Dayak, 
manakala kedudukan motif burung kenyalang yang dianggap sebagai ketua dewa dunia kayangan diletakkan pada kedudukan paling atas iaitu mewakili dan menghuni dunia atas langit yang paling atas.

Dalam aspek seni bina masyarakat Orang Ulu, motif ini lazimnya diukir pada dinding hadapan bilik ketua rumah panjang. Motif ini mendapat gelaran 'pokok kehidupan' berdasarkan kepada bentuk lukisan Kalong itu sendiri yang dihiasi dengan pelbagai jenis binatang, tumbuh-tumbuhan dan buah-buahan iaitu yang melambangkan sifat saling bergantungan dalam kalangan penduduk dalam usaha untuk mewujudkan kumpulan masyarakat yang seimbang, harmoni dan kuat. Pendek kata, ia berkisar mengenai kehidupan di sesebuah rumah panjang dalam masyarakat Orang Ulu.

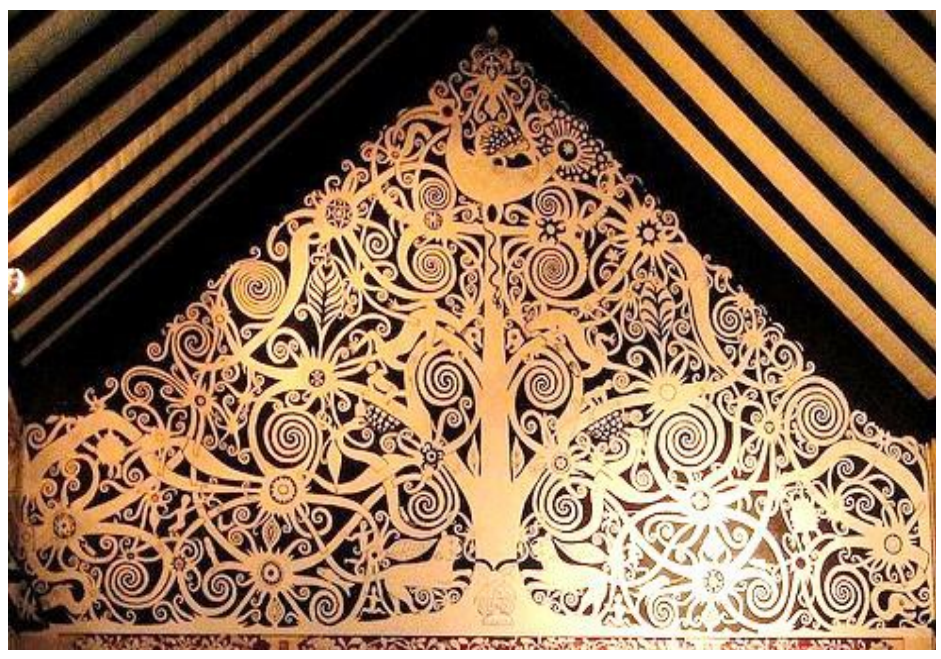

Gambar 2. Kalong Kayu Aren

\subsection{Kalong Penat}

Kalong Penat / Tarik (Gambar 3) merujuk kepada motif yang mempunyai sifat-sifat yang selari, seimbang, memanjang dan baik rupa bentuknya.

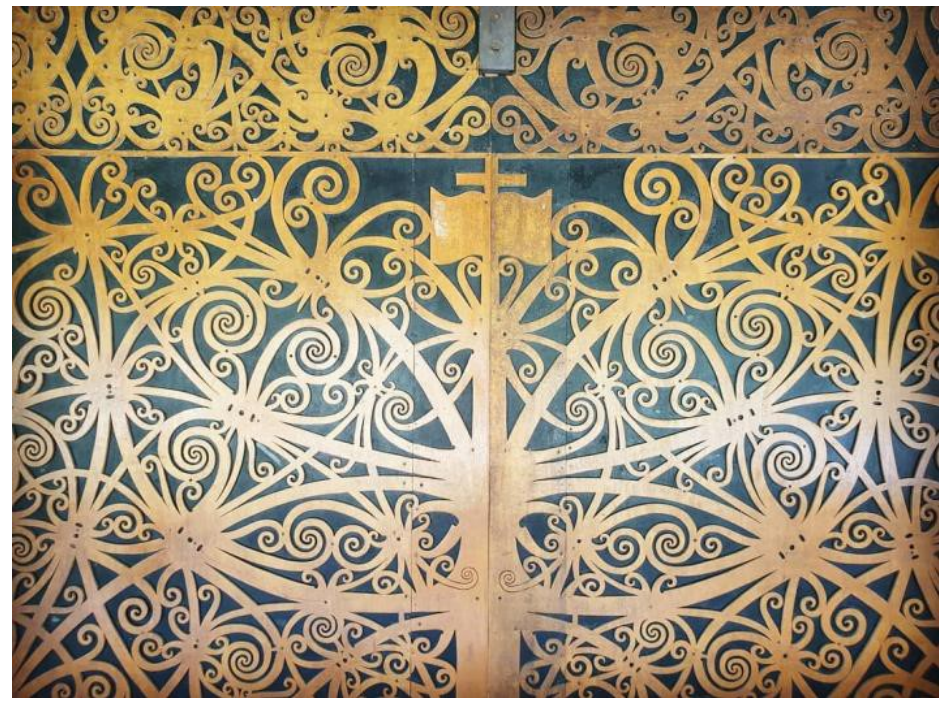

Gambar 3. Kalong Penat 
'penat' dalam bahasa Kenyah bermaksud 'tarik', melambangkan betapa baik dan cantiknya bentuk motif ini, maka masyarakat Orang Ulu telah menciptakan puisi khas untuk mengambarkan motif Kalong Penat ini.

Dalam sesebuah binaan masyarakat Orang Ulu, Kalong Penat jika dilukis pada dinding rumah panjang akan dikenali sebagai Kalong Nding (ukiran dinding) dan mempunyai persamaan dengan Kalong Kayu Aren iaitu mempunyai punca dahan. Konsep keseimbangan yang teliti dalam motif ini membawa kepada maksud persefahaman, perpaduan dan kerjasama yang tidak berbelah bahagi dalam kalangan penduduk kampung.

\subsection{Kalong Kelunan}

Kalong Kelunan / Manusia (Gambar 4) dalam masyarakat Orang Ulu menggambarkan motif bentuk manusia yang masih bergaya di zaman prasejarah dimana manusia tidak digambarkan dalam bentuk yang realistik namun figuratif. Kalong Kelunan dalam masyarakat Orang Ulu merupakan motif yang tidak mendapat sebarang pengaruh kesenian klasik seperti pengaruh kesenian Hindu dan Budha sebagaimana yang berkembang pesat di Jawa dan Bali. Motif Kalong Kelunan banyak digunakan sebagai hiasan pada dinding rumah ketua rumah panjang, alat penggendong bayi, pakaian dan kain sarung wanita serta beberapa peralatan yang lain. Motif ini melambangkan kekuasaan, kekayaan dan kepimpinan yang disegani [10].

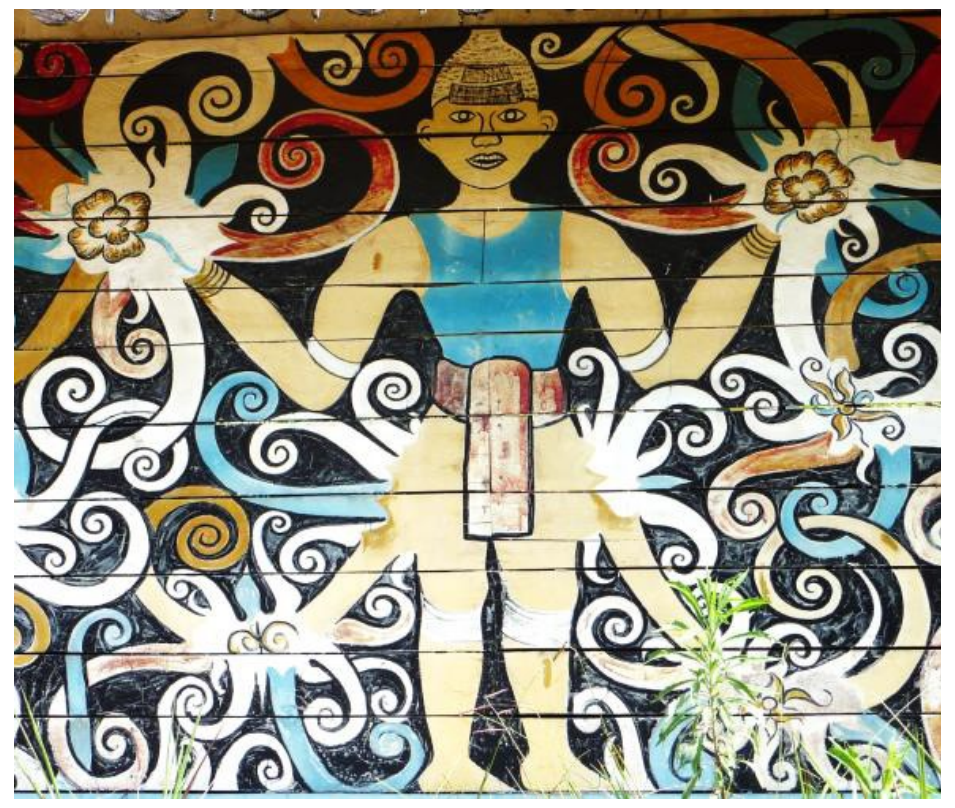

Gambar 4. Kalong Kelunan

Menurut Tillema [11] dalam kalangan bangsa Kenyah yang tinggal di Apo Kayan, hanya wanita dari golongan maren sahaja yang dibenarkan untuk memakai motif Kalong Kelunan, dan ini diwarisi secara tradisi oleh masyarakat berkenaan kerana hanya wanita daripada golongan maren sahaja yang mampu untuk menghindarkan kuasa jahat yang terkandung atau dibawa oleh motif berkenaan. Manakala menurut King [12], Kalong Kelunan merupakan lambang kepada roh hamba iaitu tawanan perang yang telah dikorbankan dalam upacara tertentu. Menurut kisahnya, motif Kalong Kelunan bermula semasa zaman mengayau. Semasa ekspedisi mengayau, pihak yang menyerang akan sedaya upaya untuk mendapatkan kepala pihak lawan dan dalam masa yang sama cuba untuk mendapatkan tawanan perang yang akan dijadikan sebagai hamba oleh golongan maren (atasan). Ini kerana dengan memiliki tawanan perang yang dijadikan sebagai hamba merupakan sesuatu yang dianggap berprestij tinggi bagi masyarakat Orang Ulu pada zaman dahulu. Oleh yang demikian, sebagai lambang berprestij ini maka motif manusia akan dilukiskan pada dinding rumah golongan maren atau ketua yang menyimpan tawanan perang tersebut. 
Pengolahan bentuk manusia iaitu motif Kelunan dihasilkan dalam dua bentuk yang berbeza iaitu yang pertama, bentuk wajah manusia iaitu dengan hanya mengambil bentuk gambaran pada bahagian wajah atau muka sahaja. Lazimnya bentuk wajah ini dihasilkan dalam sesebuah karya yang memerlukan konsep keseimbangan dan kesetaraan pada bahagian kiri dan kanan karya. Bentuk wajah manusia dalam sesebuah karya biasanya dijadikan sebagai titik tengah pada sesebuah karya iaitu sebagai asas bagi sesebuah Kalong sebelum dikembangkan dan ditambah dengan elemen-elemen dari motif sampingan sebagai pelengkap. Olahan motif-motif pelengkap yang digabungkan dan disatukan pada motif wajah manusia tersebut lazimnya menggunakan motif Kelawit-kawit kelihatan seolaholah ditarik ke semua arah pada bahagian kiri, kanan, atas dan bawah pada karya tersebut. Bentuk bahagian wajah ini biasanya dihasilkan dalam bentuk lukisan mural pada dinding-dinding binaan dan pada gubahan manik. Manakala bentuk yang kedua memaparkan gambaran figura manusia yang lengkap yang diolah secara sederhana. Bentuk ini dilukis dalam gambaran figura samada dalam posisi berdiri, duduk dan dalam posisi seolah sedang menari. Bentuk ini memperlihatkan keseluruhan figura yang lengkap.

\subsection{Kalong Aso'}

Kalong Aso' / Naga Aso' (Kombinasi Naga dan Anjing) (Gambar 5) merupakan motif yang paling popular dan diminati serta digunakan secara meluas dalam masyarakat Orang Ulu. Motif Kalong Aso' atau Naga Aso' diinspirasikan dari gabungan seekor anjing dan naga iaitu kombinasi dari bentuk naga dan anjing. Pada bahagian kepala menyerupai bentuk seekor naga, manakala pada bahagian badannya pula menyerupai bentuk badan anjing. Setiap rangkaian Kalong membentuk komposisi yang saling melengkapi, saling mencari keselarasan hubungan, dan saling mengisi. Begitu juga halnya Kalong Aso' ini yang mempunyai makna dan falsafahnya tersendiri dalam kehidupan masyarakat Orang Ulu. Motif yang diinspirasikan dari seekor anjing ini memainkan peranan yang sangat bermakna dalam kehidupan mereka. Dalam masyarakat Orang Ulu tradisional, anjing mempunyai peranan yang sangat penting dalam kehidupan mereka. Pada dasarnya, masyarakat Orang Ulu mencipta motif anjing sebagai rasa syukur atau berterima kasih kepada haiwan peliharaan mereka yang selalu menjaga dan menemani mereka pada ketika berburu serta selalu setia kepada tuannya. Selain sebagai peneman ketika berburu di hutan, anjing juga merupakan pengawal yang baik.
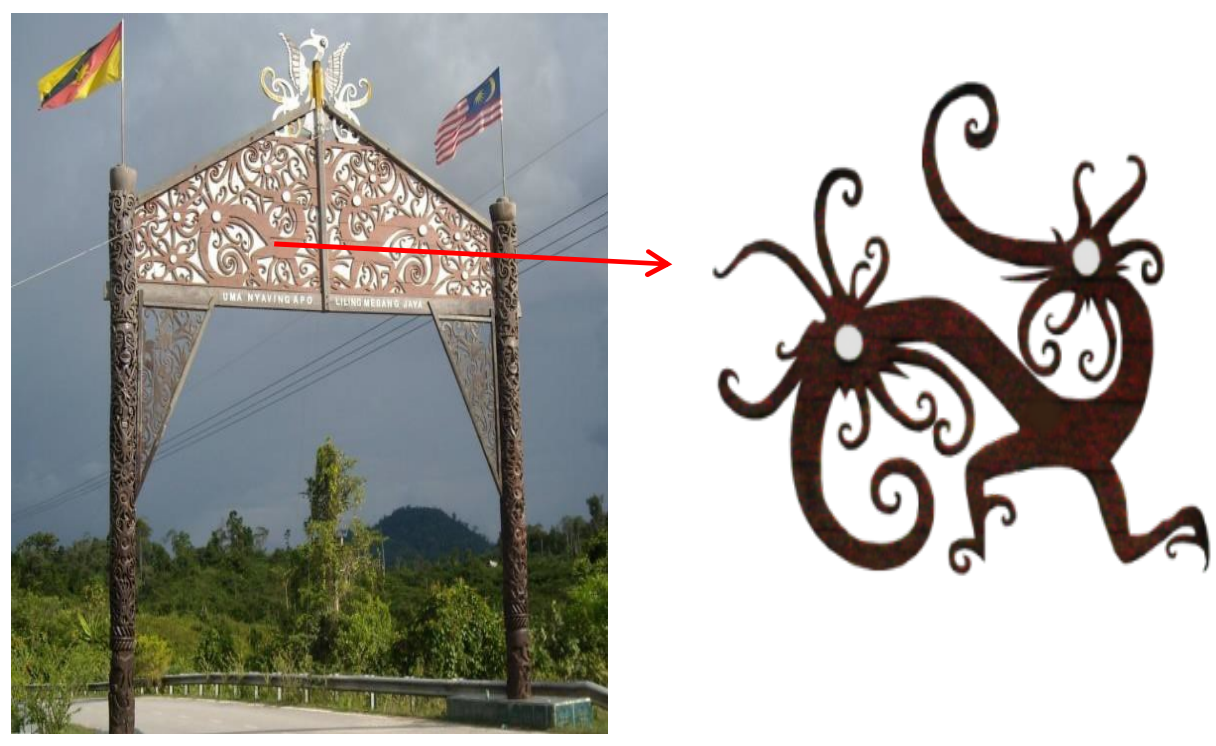

Gambar 5. Kalong Aso'

Penggunaan Kalong Aso' dalam masyarakat Orang Ulu adalah sangat meluas kerana motif ini boleh digunakan oleh semua golongan kelas masyarakat dan tidak ada pantang larang dalam 
penggunaannya. Dalam kesenian masyarakat Orang Ulu tradisional, Kalong Aso' ini banyak menghiasi setiap sudut rumah panjang mereka. Bukan hanya di rumah panjang, Kalong Aso' ini juga digubah dalam pelbagai bentuk yang sesuai dengan penggunaannya serta jenis bahan yang digunakan. Walaupun motif ini digubah dalam pelbagai bentuk, namun ia tidak boleh lari dari asas motif Kalong Aso' yang asal iaitu kombinasi dari bentuk naga dan anjing masih dikekalkan. Motif Kalong Aso' digubah sebagai motif hiasan pada pakaian tradisional, perhiasan dan senjata serta peralatan lain atau digunakan sebagai motif untuk cacah badan (tattoo).

\subsection{Kalong Tebengang}

Motif Kalong Tebengang (Enggang) lazimnya dilukiskan pada bahagian atas atau tengah pada sesuatu motif dan bersimbolkan burung enggang (Buceros rhinoceros). Motif ini selalunya dikaitkan dengan roh atau semangat yang menyampaikan pesanan atau mesej kepada masyarakat Orang Ulu.

Menurut Robert L. Winzeler [13] dalam bukunya the Architecture of Life and Death in Borneo: "...the hornbill is regarded as one form of the chief upper world deity".

Ini menjelaskan bahawa burung enggang dianggap sebagai ketua dewa dunia kayangan dalam kepercayaan masyarakat Dayak.

Manakala Joshua Eliot dan Jane Bickersteth [14], melalui buku yang berjudul Malaysia Handbook: The Travel Guide menjelaskan bahawa masyarakat Dayak menganggap bahawa burung enggang mempunyai kuasa luar biasa dan dilihat sebagai sebuah simbol kepahlawanan. Oleh yang demikian, penggunaan motif burung enggang dalam masyarakat Orang Ulu melambangkan status kebangsawanan seseorang dan lazimnya motif ini hanya dipakai oleh golongan paren dan pemimpin sahaja contohnya, hanya terdapat pada rumah atau ruang yang dihuni oleh ketua suku atau pemimpin. Ini menjelaskan bahawa burung enggang dianggap sebagai ketua dewa dunia kayangan dalam kepercayaan masyarakat Dayak. Mereka menganggap bahawa burung enggang mempunyai kuasa supernatural dan dilihat sebagai sebuah symbol kepahlawanan. Motif ini selalunya dikaitkan dengan roh atau semangat yang menyampaikan pesanan atau mesej kepada masyarakat Orang Ulu. Burung enggang biasanya sering terlihat di puncak-puncak pohon yang tinggi. Oleh itu burung ini menjadi simbol dari sesuatu yang berasal dari tempat tinggi, maka penggunaan Kalong Tebengang pada sesebuah binaan atau bangunan lazimnya akan ditempatkan pada bahagian atas atau tertinggi pada bangunan tersebut seperti pada struktur atau bumbung sesebuah binaan. Ini kerana dalam kepercayaan tradisional masyarakat Orang Ulu, mereka menganggap burung kenyalang sebagai dewa yang paling berkuasa [15].

\section{Kalong Dalam Senibina Masyarakat Orang Ulu}

Ragam hias pada sesebuah bangunan tradisional adalah berdasarkan kepada falsafah yang terkandung di sebalik simbol-simbolnya yang kompleks. Menurut Koenjaraningrat [16], bentuk ukiran bermula sejak manusia mulai mengukir dan menggambarkan binatang buruan mereka pada dinding gua, alat keperluan, kepercayaan ghaib dan keagamaan. Akhirnya gambaran dan ukiran tersebut menjadi lambang atau simbol dan dengan evolusi itu, maka timbullah motif perhiasan dalam kesenian manusia. Pernyataan ini menjelaskan bahawa penciptaan motif dalam sesebuah masyarakat pendukungnya adalah berkait rapat dengan situasi kehidupan masyarakat tersebut, baik dari segi kerohanian dan kebudayaan serta interpretasi mereka terhadap alam. Ragam hias Kalong dalam masyarakat Orang Ulu, selain digunakan pada barang-barang perhiasan dan kraftangan serta barangbarang peribadi, Kalong juga digunakan pada binaan-binaan penting seperti pada dinding atau beranda rumah panjang, rumah adat, tiang, pintu dan pintu gerbang, perahu, tempat perkuburan atau rumah persemadian dan pondok tempat penyimpanan padi.

Dalam konteks masyarakat Orang Ulu, setiap binaan yang penting akan diberi tanda hiasan dan sesebuah binaan tersebut tidak boleh lari daripada penggunaan Kalong. Binaan-binaan dalam masyarakat Orang Ulu yang dibina pada masa lalu secara umumnya dihiasi dengan komponen berukir, baik yang berupa ornament atau ragam hias atau berupa pahatan, lukisan mahupun ukiran yang menggunakan motif Kalong sebagai motif utama. Hasil ukiran kayu yang baik bukan sahaja dapat menyerikan binaan-binaan tersebut, malah dapat menimbulkan ciri-ciri pertukangan yang amat mengkagumkan. Ini menunjukkan kepekaan tukang ukir terhadap objek alam yang dimanifestasikan kepada bentuk-bentuk abstrak dengan nilai-nilai falsafah yang tersirat. Motif-motif Kalong yang terdapat pada seni bina masyarakat Orang Ulu tradisional lazimnya menggabungkan teknik ukiran dan lukisan dan memerlukan kemahiran tangan yang tinggi. 


\section{Kesimpulan}

Manusia mempunyai kecenderungan bersuara dan berkarya seni dengan berorientasikan kepada lingkungan dan alam sekitarnya. Lingkungan alam sekitar telah menyediakan banyak sumber inspirasi untuk mewujudkan idea-idea yang boleh digunakan oleh masyarakat dalam berkarya, manakala budaya memberikan arah kepada masyarakat Orang Ulu bagaimana untuk berhadapan dengan kesemuanya. Motif ragam hias Kalong dalam masyarakat Orang Ulu diilhamkan daripada bentuk tumbuh-tumbuhan, makhluk hidup yang melata baik di darat mahupun di air serta di udara, digubah dan disusun dalam membentuk seni motif yang harmoni. Kesenian sebagai unsur kebudayaan tidak hanya dilihat dari hasil ciptaannya semata -mata, tetapi dalam hal ini lebih dipandang sebagai simbol iaitu mengatakan sesuatu tentang sesuatu.

\section{Rujukan}

[1] Siti Zainon Ismail, Reka Bentuk Kraf Tangan Melayu Tradisi. Kuala Lumpur: Dewan Bahasa dan Pustaka, 2018.

[2] Dedi Suardi, Ornamen Geometris. Bandung: Rosdakarya, 2000.

[3] H. C. Omar, N. M. R. Yusoff, Bahasa verbal dan bukan verbal II: Linguistik, sastera dan peradaban, 1st ed. Kuala Lumpur: Institut Terjemahan Negara Malaysia Berhad, 2009.

[4] H. Kusantati, Keterampilan. Bandung: Grafindo Media Pratama, 2007.

[5] Guntur, Ornamen, Sebuah Pengantar. Surakarta: STSI Press, 2004

[6] H. Frick, Pola Struktural dan Teknik Bangunan Indonesia. Yogyarkarta: Kanisius, 1997.

[7] J. Jalong, Kalong: Seni Motif Tradisi Orang Ulu, 1st ed. Kuala Lumpur: Kementerian Kebudayaan Kesenian dan Pelancongan Malaysia, 2001.

[8] R. L. Winzeler, The Architecture of Life and Death in Borneo. Honolulu: University of Hawai'i Press, 2004.

[9] G. Augustine, Asas Ukiran Iban: Suatu Pengenalan. Kuala Lumpur: Dewan Bahasa dan Pustaka, 1991.

[10] Munan and Heidi, "Social Status Gradations Expressed in the Beadwork Patterns of Sarawak's Orang Ulu," Journal Beads: Journal of the Society of Bead Researchers vol. 7, pp. 55-64, 1995

[11] H. F. Tillema, A Journey Among the Peoples of Central Borneo in Word and Picture. Amsterdam: Van Munsters Vitgevers, 1938.

[12] King and T. Victor, "Symbols of Social Differentiation: A Comparative Investigation of Signs, the Signified and Symbolic Meanings in Borneo," Antropos Journal, vol. 80, pp. 125-152, 1985.

[13] R. L. Winzeler, The Architecture of Life and Death in Borneo. Honolulu: University of Hawai'i Press, 2004.

[14] J. Eliot, J. Bickersteth, Malaysia Handbook: The Travel Guide. UK: Footprint Travel Guides, 2002.

[15] Sahari, Faridah, A. Durin, and S. E. Sangin. "Cabaran dan peranan pembuat kraf dalam pelestarian budaya benda masyarakat Orang Ulu di Belaga Sarawak." Borneo Research Journal, vol. 10 pp. 111-126, 2016.

[16] Koentjaraningrat, Pokok-Pokok Antropologi. Jakarta: Gramedia Pustaka Utama, 1996. 